\title{
Effects of Iran's WTO Accession on the Cement Industry: A Dynamic Disequilibrium Adjustment Model (DDAM) of Simultaneous Equations
}

\author{
Bijan Bidabad $^{1}$ \\ Nahid Kalbasi Anaraki ${ }^{2}$
}

\begin{abstract}
Many companies around the globe are re-examining their business operations to explore profitable growth in international markets. The attractiveness of the membership in WTO can be recognized not only in the growing number of its members but also as a result of increasing access to potential markets around the world. Iranian economy suffers from huge inefficiency in its trade relationships with other countries due to import compression policy and strict import controls. Iran's import profile is heavily skewed towards those tradable that are not strongly under the effects of WTO, indicating protectionism policy in the industry sector. Besides the need for easing protectionism, the emphasis placed on the growth of non-oil exports and reducing oil dependency as an objective in the five-year development plans provides a strong argument for joining WTO. Measuring technical efficiency in the cement industry in Iran suggests that companies with export-orientation policy have potentials to succeed in increasing their technical efficiency.The new discovering realm of WTO for Iran's trade policy has been evaluated in this paper. The pros and cons for joining induced us to investigate the effects of Iran's membership on the cement industry. By designing a dynamic disequilibrium adjustment model (DDAM), we use annual data for the period 1963-2002 to estimate a simultaneous system of econometric equations including cement supply, exports, imports, and consumption functions in order to quantify the effects of joining on the cement industry of Iran. One of the main challenges confronting the Iranian cement industry is to improve the competitiveness of the industry by reducing the subsidies, removing restrictions, and price controls. Indeed, the experience of other counties after joining WTO portrays a conflicting profile on the effects of accession on domestic economies. While some countries have developed important trading partners, others have suffered due to the loss of domestic industries. In this paper, we intend to examine the hypothesis of whether reducing the tariff rates will promote Iranian cement industry. The results reveal that joining WTO has negligible effects on consumption, production, and exports, though, will raise imports substantially.
\end{abstract}

Keywords: Cement Economics, Dynamic Disequilibrium Adjustment Model, DDAM, WTO, Econometric Model

\section{Introduction}

Iran has a special geographical advantage regarding mining products international trade due to locating in the Persian Gulf region with high potentials since mineral products have been among the top ten imports of the Persian Gulf region. Due to import compression policy and strict import controls, Iran's import as a share of GDP is relatively low. Moreover, her import profile is heavily skewed towards bulk foodstuffs and essential capital goods, reflecting recent currency shortage, import bans on many products and heavily protected industrial base. However, higher oil revenue since 2000 has eased pressures on Iran's

\footnotetext{
1 - (B.A., M.Sc., Ph.D., Post-Doc.) Professor Bijan Bidabad, Fars-o-Khozestan Cement Co. economic advisor. This paper has been prepared by the order of Fars-o-Khozestan Cement Co. and the authors acknowledge financial support of this company. The views expressed herein are those of the authors and not necessarily those of Fars-o-Khozestan Cement Co. presented at the 4th European Cement Conference Barcelona, Spain 14-17 March 2004.

2 -Dr. Nahid Kalbasi Anaraki, Fars-o-Khozestan Cement Co. economic consultant.
} 
debt obligations, permitting the growth of imports in the essential goods. Though, the cement imports as a share of GDP still stands at a very low level and is estimated to reach $0.025 \%$ in 2004.

Iran's cement is a 70 years old industry. The Iranian cement industry dates back to 1993 when the first manufacture established in Rai city. Trends of consumption, production, and trade show that Iran has a more or less closed cement economy due to import restrictions and export bans in specific years. As fluctuations of cement demand and supply clarify, whenever the price of oil grows up, demand increases due to increasing government development expenditures. As a result, excess demand appears, cement price increases and the import of cement grows up. To respond to the excess demand, cement producers try to enlarge cement production capacity with some lags, and after few years excess demand is removed by domestic supply, instead of imports. For many years, this was the case for the Iranian economy. According to this dynamic procedure, we try to build up a dynamic disequilibrium adjustment model (DDAM) to explain this phenomenon. But before going through this procedure, we will have a closer look at the cement industry with an emphasis on its output and trade.

Production: This section portrays a profile of the industry production. Cement output has experienced sharp fluctuations during the period under investigation, 1963-2002. Though cement production has increased by an average annual growth rate of 10 percent during the mentioned period, it stands at a very low level compared with other developing countries like China, India, and Korea. Indeed, the industry has produced above the nominal capacity due to demand pressures and restricted imports. Over the period 1973-1978 with the oil shock and sharp increase in oil revenues cement production increased dramatically. However, after then and during the imposed war, the production plunged due to the war damages and scarcity of foreign exchange resources. The industry experienced a negative growth rate of $3.6 \%$ in 1988 due to unused capacity and reduction of productivity. However, during the post-war era, the production turned to an increasing trend due to the reconstruction activities in such a way that the output growth reached 16.7 percent in 1990.

Supply has exceeded the demand growth with the establishment of new plants and with the reduction in government expenditures since 1997. However, lack of access to international markets has induced cement producers to reduce their production due to the restriction imposed on cement exports.

Imports and Exports: Word trade of cement stands at a lower level than its production since the raw material for production are abundant and generally found in most parts of the world. Despite the low ratio of world cement trade to the world production (7 percent in 1995), the growth of the cement trade has exceeded that of output due to the high volume of trade in South East Asia. Cement imports have been close to zero during the period under investigation except for the mid-1970s when Iran confronted with a sharp increase in its oil revenues. However, this trend turned dramatically during 1975-1995, leaving the industry without any competitors due to a high level of protection, which has adversely affected the productivity of the industry.

With the increase in the demand during the 1970s, domestic production failed to respond the aggregate demand, and as a result of this failure, the cement import increased substantially, recording a growth rate of $134 \%$ in 1977, compared with the previous year. Though cement import has been relatively stable during the 1980s and 1990s, it experienced gradual growth in the early 2000s due to reconstruction activities and higher growth of the real-estate sector of the economy compared with other sectors.

Indeed, Iran's cement imports and exports have been subject to tariff and non-tariff barriers. Despite the cement shortage during the war, exports were subject to the permission of the ministries of commerce and mining. Although exports incentives and tax exemptions were introduced in 1987, the instability of policy decisions and export bans in specific years contributed to the low growth of exports. For instance, the export of different types of cement and clinker was abandoned in 1996 and 1997. However, the 
government was induced to remove exports barriers in order to avoid greater loss of manufactures in the following years.

Graph (1). Iran's cement imports and exports

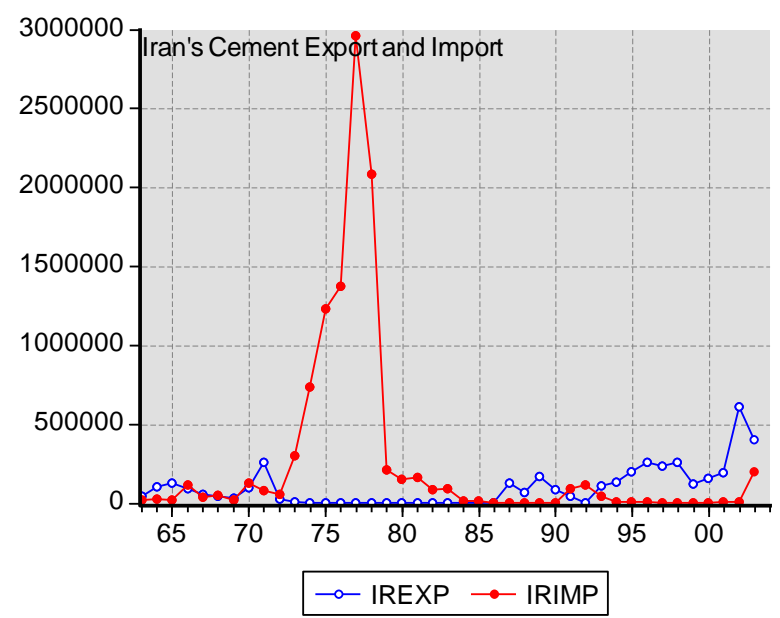

Pricing: Administrative controlled prices during the 1980s and 1990s have led to the low production of cement industry compared with other developing countries. It is worthwhile mentioning that a major factor contributing to cement prices is personnel expenses, which makes up 34 to 42 percent of the total costs, whereas the share of raw materials in total costs does not exceed 6 to 7 percent. The share of energy expenses and foreign exchange resources amounts to 18 and 14 percent of total costs, respectively.

During the post-war era, the distribution and pricing policy was under the control of the government through the "Cement Planning Committee" established in the management and planning organization (MPO). According to the regulations approved by this committee, cement producers were obliged to deliver their products to the ministry of commerce. With the end of the war in 1988, the distribution came under the control of the ministry of industries within the framework of a rationing system, and the share of the private sector, capital expenditures, and public sector amounted to 50, 40, and 10 percent, respectively.

A major challenge confronting the Iranian cement industry is administrative controlled prices. As it is seen in Table (1), controlled prices have been fixed for a long period of time during 1982-87 and have huge gaps with international prices. For instance, the controlled price in Iran has been $\$ 17.1$ per ton, compared with $\$ 78.5$ of the world price in 2000 , which is almost less than one-fourth of the world price. Indeed, the prices have been kept at very low levels artificially as a result of the high amount of revealed and disguised subsidies which have been allocated through the central government.

With the exchange rate unification in 1990-91, and due to the increasing gap between the controlled and mark-up prices, there has been increasing pressures on domestic prices. With the start of the privatization program and the increase in the personnel and energy expenses, and with the increasing gap of the official exchange rate with the parallel black market exchange rate, the loss-making enterprises were unable to bear depreciation costs and as a result prices were liberalized in 1992, though still stand at much lower level than the world prices. Since then, the equilibrium prices have been set through adding the book price with a margin profit rate set by the "Production and Distribution of Cement Committee" including the members of "Protection of Producers and Consumers Organization (PPCO)", ministry of industry and management and planning organization (MPO). Meanwhile, producers were allowed to distribute the production of higher than 90 percent of the nominal capacity and the cement enterprises were obliged to 
pay $\$ 0.9$ to the ministry of industries for each ton of cement they deliver in order to help the cement projects. In addition, the PPCO received the following share from each ton of sold prices.

Share of $\mathrm{PPCO}=.9[$ sold price $-($ mark-up price+5000Rls)]

However, the consumer price was calculated by adding up the mark-up price to 15 percent margin of profit and 1 percent municipalities' fee, 2 percent ministry of education fees, and $\$ 0.5$ for helping the ministry of economic affairs and finance.

Although considering 15 percent margin of profit rate for produces has alleviated the financing problem of energy inputs and personnel expenses, this method of pricing has failed to cover the depreciation costs. In addition, the prices are lower for the older plants due to lower mark-up prices.

As Table (1) suggests, the price of cement has been relatively stable during the post-war period throughout 1982-1990. However, since the early 1990s, the controlled price has jumped up dramatically and has reached \$ 17.1 in 2000, which is around one-fourth of the world price, \$78.5.

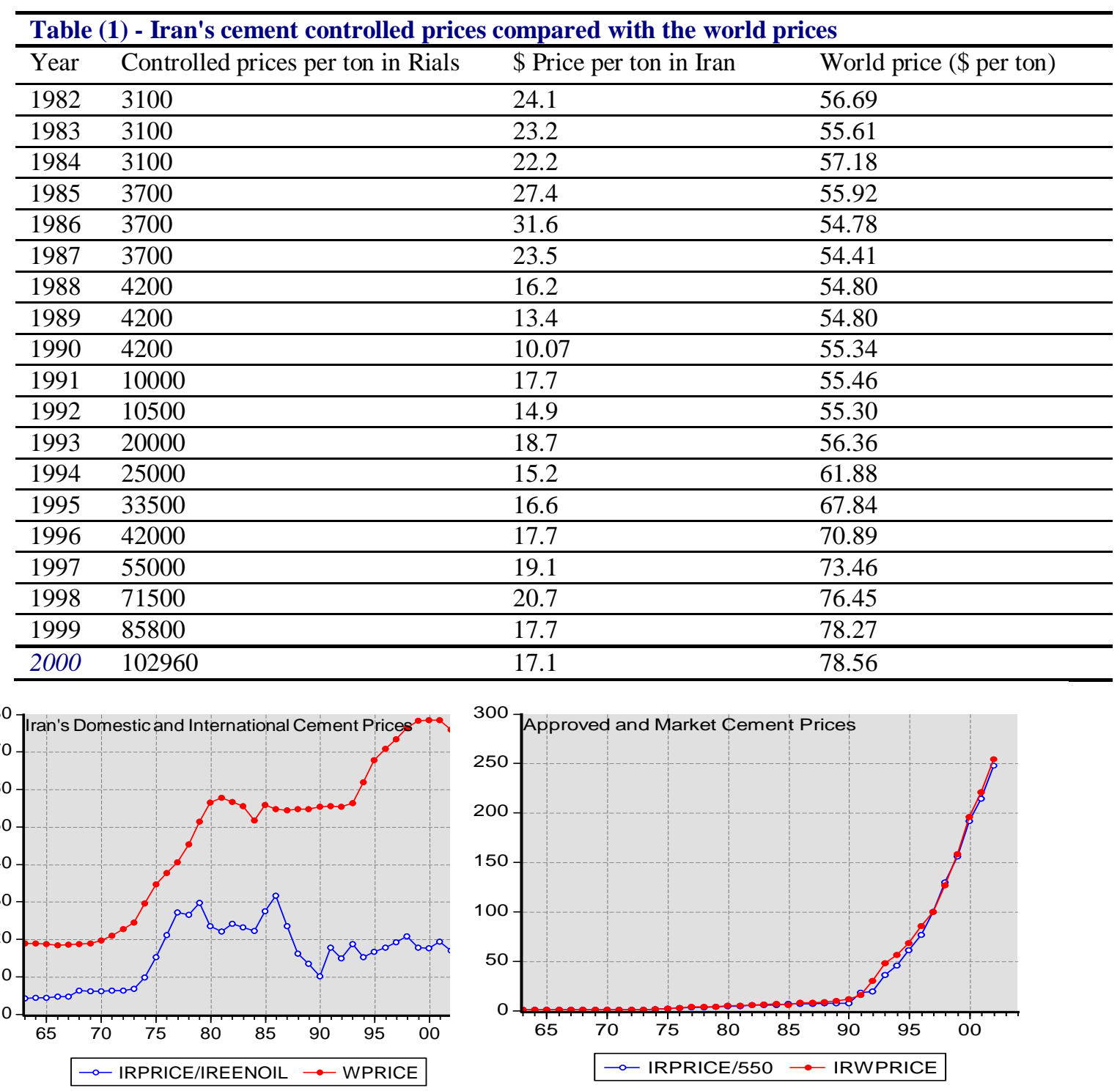

Graph 2.

Iran's cement controlled prices and the wholesale price index of cement 


\section{Literature Review}

Unfortunately, little empirical study has been carried out on the cement industry of Iran. Ramin Dadras (1999) tries to measure the technical efficiency of the industry, using Stochastic Frontier Translog Production and Cobb-Douglas functions. ${ }^{3}$ The estimated results suggest that the inefficiency has increased during the time, and the ownership type and presence of exports affect the efficiency of the industry. Moreover, the estimated elasticities for the Translog function suggest increasing returns to scale in the cement industry. The estimated elasticities with respect to capital and labor according to the Translog function are 0.82 and 0.22 , respectively. The estimated technical efficiency of the industry according to the Translog function and Cobb-Douglas functions amounts to 0.87 and 0.85 , respectively. Put differently; the industry has produced 13 percent less than it could, given the amount of inputs and energy.

As it is seen in Table (2), mean of efficiency has jumped up since 1992, with the start of the First Five Year Development Plan. However, since 1994, the industry has experienced a decreasing trend of technical efficiency. This shift, in turn, is attributed to the excess supply and to a substantial reduction in government expenditures in infrastructure and real estate sectors. As a result of the excess supply, the number of enterprises forced to export their products increased from 8 in 1994 to 13 in 1996. However, cement export bans in 1996 acted as a slash to the efficiency of the industry. It is worthwhile mentioning that some of the enterprises have experienced stable efficiency during the period under investigation. For example, Fars Cement and Sepahan Cement enterprises have experienced stable efficiency during the time and the highest amount of efficiency in the sample, whereas Khazar Cement Co. had the lowest efficiency score.

Since 1994 with the entry of the cement enterprises to the Tehran Stock Exchange (TSE) efficiency has decreased substantially. However, one cannot argue that the decreasing trend of efficiency can be attributed to the accession to TSE. Indeed, one of the main reasons for the decreasing trend of efficiency is the instability of regulations governing exports of the industry, particularly, exports bans in 1996 and 1997.

Table (2)-Technical efficiency of the cement industry in Iran during 1991-1997

\begin{tabular}{lrrrrrrr}
\hline & \multicolumn{1}{c}{1991} & \multicolumn{1}{c}{1992} & 1993 & 1994 & 1995 & 1996 & 1997 \\
\hline Number of plants & 9 & 13 & 14 & 15 & 16 & 16 & 16 \\
\hline Mean Efficiency & 0.80 & 0.90 & 0.91 & 0.89 & 0.87 & 0.88 & 0.85 \\
\hline Standard Deviation & 0.10 & 0.06 & 0.05 & 0.06 & 0.16 & 0.14 & 0.11 \\
\hline Minimum & 0.59 & 0.73 & 0.76 & 0.73 & 0.27 & 0.40 & 0.50 \\
\hline Maximum & 0.93 & 0.95 & 0.95 & 0.95 & 0.95 & 0.96 & 0.94 \\
\hline
\end{tabular}

Source: Dadras, Ramin, "Measuring the technical efficiency of the cement industry in Iran, a dissertation guided by B. H. Zonooz, Allameh University, 1999

In another study, Morteza Sameti $(1995)^{4}$ measures the efficiency of cement industry in different sectors. His sample includes four cement companies, two public enterprises, one private, and one cement company affiliated to the Mostazafan and Janbazan Foundation, which is a semi-government organization. He uses a Cobb-Douglas production function to measure the efficiency of the production. The estimated results suggest that the elasticity of production with respect to the labor force for Tehran Cement Company, which is affiliated to the Foundation, has had the highest elasticity score. The private cement company, Shargh Cement Co. stands at the second level, and finally, the public sector companies have had the lowest elasticities.

\footnotetext{
3 -Dadras, Ramin, "Measuring the technical efficiency of the cement industry in Iran, a dissertation guided by B. H. Zonooz, Allameh University, 1999.

${ }^{4}$-Sameti M., "Reducing Government Interventions", Ministry of Economic Affairs and Finance, 1995.
} 
He also has estimated the productivity of the labor force in different companies. His results indicate the highest level of labor productivity in Tehran Cement Co. and the lowest level in public sectors companies. However, with respect to capital productivity, the private sector company has experienced the highest productivity level.

Finally, a long-run total cost function has been estimated with pooling data on different companies with different types of ownership. The estimated results indicate that the Tehran Cement company has had the lowest production costs and then the private sector and public sector companies stood at the second and third levels, supporting the estimated results of productivity. Put differently, companies with higher productivity have experienced lower production costs. Indeed, the estimated results suggest that public sector enterprises confront with higher costs since they have been assured of receiving a large amount of government subsidies and has taken no important invention to reduce their operating costs.

\section{WTO and countries experiences}

The treaty negotiated during the Uruguay round established the WTO, the international institution to govern the world trade. The success of GATT as a dynamic institution that has fostered dramatic increase in worldwide trade lies in its founding principles of most favored nations treatment (MFNT), voluntary export restrictions (VERs), orderly marketing arrangements (OMAs), rules of origin, government procurement, safety rules, market access commitments and reciprocity and non-discrimination. Thus, nondiscrimination extends the benefits of a reciprocal tariff reduction beyond the two parties. Nondiscrimination is a convenient way to reduce the complexity of international trade relations. As an importer, a country can charge a single nondiscriminatory tariff on imports from all countries, or it can set different tariffs on imports from different countries. Under a nondiscriminatory tariff system, imports will be sourced from the lowest-cost producers in the world. When a country uses a nondiscriminatory tariff, this facilitates the allocation of resources worldwide to their most productive uses.

Countries' experiences portray a contradictory profile. While some countries like China have benefited from joining WTO, others have suffered due to the loss of domestic industries. In China, foreign investment is playing an increasingly important role in shaping up the Chinese market. In 1998, there were 287 foreign-invested enterprises accounting for about 3\% of all cement producers and $15 \%$ of national output. China is the world's second-largest cement exporter, accounting for about $17 \%$ of total global cement trade. China had cut the average tariff level of imported goods from 15.3 percent to 12 percent in 2002; this reduction is fully in conformity with the commitment China has made for its accession to the World Trade Organization. Indeed, WTO accession should not have much of an impact on the cement industry, as a tariff on cement and clinker dropped only from 12 percent to 10 percent in 2001 and is not due to falling any further. In sum, China's experience reveals a success story because domestic protection has not stood at high levels before joining WTO.

Taiwan is another success story. Before the accession, the average levels of tariffs on imports of industrial and agricultural products into Taiwan were 6.03 and 20.02 percent, respectively. Upon accession (2002), the two figures were reduced to 5.78 and 14.01 percent, respectively. Following the completion of all the scheduled tariff reductions on the 3470, industrial and 1021 agriculture products for which Taiwan has made commitments; the average levels of tariffs applied on industrial and agricultural products fell further to 4.15 and 12.86 percent, respectively. The economic impact of its WTO membership on the economies of its trading partners, as well as Taiwan itself, will be worth billions of dollars annually. According to a recent report by the Council of Economic Planning and Development (CEPD), Taiwan's GDP is likely to expand by an additional 0.77-4.7 percent in the first five to ten years of WTO membership.

Others, like Indonesia, confronts a possible crisis. When the crisis was at its peak in 1998 in Indonesia, the utilization rent of cement industry went down to 50 percent. This forced the producer to export at lower margins than those available in the domestic market. Indonesia exported some 4.5 million tons of 
cement and clinker in 1998 following the plunge in domestic demand, while production reached 22 million tons per year. The increasing cement exports since the crisis pushed export's share of total cement production from 1 percent in 1996 to 33 percent in 1999. Though there was an increase in exports, the country's total cement production continued to decrease as domestic consumption dwindled. Now that increasing domestic demand has pushed up the cement industry back to its pre-crisis levels, the Indonesian Cement Association (ASI) has signaled that cement exports would likely decrease. Last year, exports reached around 8 million tons. However, the increasing domestic demand could bring about a rising crisis in the years to come if the present production capacity is not increased. As itself, has projected a problem will rise in the cement supply in the coming years because the growth of product capacities would be less than the average of 3-5 percent growth rate of demand. To prevent a possible crisis, new plants, and more supply of raw materials are needed. To encourage investment, the government could provide such incentives as tax holidays.

WTO membership and associated trade liberalization are crucial for the Persian Gulf region's future economic prospect, lifting economic growth and boosting foreign investor confidence. Oman, Saudi Arabia, and Yemen have applied for membership and are negotiating entry conditions, although Yemen's accession is in its infancy. Iran's application for WTO membership has not been scheduled for consideration due to US opposition. Indeed, WTO membership is an important driver of reform, limiting the amount of protection. Trade liberalization, particularly elimination of subsidies, protection of intellectual property rights, and equal treatments for domestic and foreign companies are all requirements of WTO memberships. Members also must remove non-tariff barriers, such as certification, licensing, government procurements, and inspections not in accordance with WTO rules. Oman's accession is imminent. The accession process has driven major reforms. Oman has agreed to liberalize tariff and bind tariff commitments for agricultural exports as well as minerals, cars, information technology products, chemicals, paper products, and construction materials. Oman has also agreed on no tax discrimination between domestic and foreign companies and has increased foreign ownership limit from 49 percent to 70 percent.

Saudi Arabia WTO accession has important domestic and regional implications, given the Saudi economy's size. Saudi Arabia's unilateral foreign investment liberalization announcement in April 2000 and its improved tax treatment for foreign companies already have placed the region countries like UAE under pressure to improve their treatment of foreign investors. Bilaterally agreed market access improvements, which will apply to all WTO members, will yield significant benefits. Multilateral negotiations also could yield major improvements in access to the Saudi Arabia market via reduced agriculture subsidies, fewer quantitative restriction, improved intellectual property rights, equal tax treatment for domestic and foreign companies, and improved customs procedures.

Indeed, countries' experiences reveal that a crucial factor affecting success story of countries is the structure of the domestic industry and the level of protection on the domestic industry before joining WTO. Countries that have already reduced their tariff rates before joining WTO more likely will benefit from entry, though, countries with high tariff rates that need to liberalize their domestic markets to imports suddenly will more likely confront with potential losses.

\section{Tariff and non-tariff barriers in Iran}

Tariff barriers vary substantially across the Persian Gulf economies; Kuwait and the UAE have the lowest average tariffs around 3.5 percent, and Saudi Arabia has had the highest tariff rates among Arab countries. In the UAE, most tariffs are 4 percent, although around 75 percent of import is duty-free including foodstuffs, medicines and public sector imports. Saudi Arabia's simple average tariff rate is 12.5 percent. Imports of basic foodstuffs and medicines are duty-free, with a general 12 percent tariff on most other imports, and a 20 percent tariff on many imports which also are produced locally. 
Qatar: The general tariff rate is 4 percent, but tariffs of 20 to 30 percent apply to goods competing with local products such as cement, steel, and urea.

Bahrain: Imports of raw materials, semi-manufactured goods, and products for development projects or re-exports are duty-free. Tariff starts at 5 percent on foodstuffs and necessities, and as in many other regional economies, much higher rates apply to cigarettes (50 percent).

Oman: A wide range of essentials consumer goods enter duty-free, as do industrial inputs. Luxury consuming goods, including tea, coffee, and prepared foods, attract 15 percent tariff, while cars incur 10 to 15 percent tariff rates depending on the engine size.

Yemen: Since 1996, as part of the IMF sponsored reform program, tariffs have fallen to the domain of 5 to 25 percent.

Iran: Most consumer goods imports incur 30 to 50 percent tariffs. Capital and intermediate goods attract lower tariffs, while medicines, wheat, and other strategic/essential goods are duty-free, and non-essential imports are often banned. Indeed, the cement industry has been heavily regulated through tariff and nontariff barriers on cement imports and exports, resulting in a low level of trade compared with domestic production. To review the tariff and non-tariff barriers in Iran, we focus on the data in 1999, the most recent available data on tariffs. According to export-import regulations, goods and commodities are categorized under 21 sectors.

Table (3) presents the minimum, maximum, and average tariff rates of different categories in 1999. As it is seen, the lowest tariff rate applies to chemical industries among different sectors. The cement industry in the fifth category has experienced an average tariff rate of 35.7 percent. Indeed, the cement industry has been relatively less protected than sectors like food industries or textile; however, has been heavily protected compared with sectors like chemical industries with an average tariff rate of 18.9 percent. Moreover, the industry has confronted with export bans in specific years, especially in 1995 and 1996. Indeed, the high level of tariff and non-tariff barriers has contributed to a low level of cement production in Iran.

Comparing average tariff rates in Iran with other countries, as revealed in Table (4), shows that Iran has experienced a much higher level of protection. For instance, the average tariff rates in the industrial sector in Turkey, Singapore, and Philippine amounts to 5.7, 2.7, and 9.1, respectively. Even compared with Thailand with an average tariff rate of 43.7, and India with an average tariff rate of 29.5, Iran has experienced much higher tariff rates in some industries including food and textile. The matter of the fact is that Iran's protectionism policy has been very intense compared with other developing countries leading to smuggling and trafficking of goods due to the high amount of subsidies allocated to some sectors through the central government.

With a new era of international trade, many countries have reduced their tariff and non-tariff barriers to be eligible to join WTO. The research studies carried out in developing countries suggest that amount of reduction in tariff rates vary substantially depending on trading partners, the composition of foreign trade, the structure of the ownership, and the level of protection before joining WTO.

Table (3). Average tariff rates for different categories in Iran (1999)

\begin{tabular}{|c|c|c|c|c|c|}
\hline Category & Items & $\begin{array}{l}\text { No of } \\
\text { tariffs }\end{array}$ & $\begin{array}{c}\text { Min } \\
\text { tariff }\end{array}$ & $\begin{array}{c}\text { Max } \\
\text { tariff }\end{array}$ & $\begin{array}{c}\text { Average } \\
\text { tariff }\end{array}$ \\
\hline 1 & Animal and animal products & 201 & 0 & 180 & 62.3 \\
\hline 2 & Vegetables, fruits and wheat & 271 & 0 & 200 & 85.9 \\
\hline 3 & Soya bean oil and non-vegetarian oil & 46 & 0 & 175 & 55.0 \\
\hline
\end{tabular}




\begin{tabular}{llllll}
\hline 4 & Food industry, beverage, and tobacco & 186 & 0 & 200 & 103.7 \\
\hline 5 & Mineral products & 148 & 5 & 110 & 22.6 \\
\hline 6 & Chemical industries and related items & 786 & 0 & 210 & 18.8 \\
\hline 7 & Crude rubber and caoutchouc & 198 & 5 & 215 & 38.5 \\
\hline 8 & Leather and leather made commodities & 74 & 5 & 215 & 127.1 \\
\hline 9 & Wood and wood products & 81 & 5 & 215 & 71.6 \\
\hline 10 & Paper and paper products & 148 & 5 & 135 & 37.9 \\
\hline 11 & Textile and related items & 824 & 10 & 270 & 109.0 \\
\hline 12 & Shoes, umbrella, and sun-glasses & 55 & 120 & 220 & 204.7 \\
\hline 13 & Chalk, asbestos, tile, and glass & 147 & 5 & 220 & 78.3 \\
\hline 14 & Pearl. Precious stones and gold & 52 & 5 & 270 & 39.0 \\
\hline 15 & Non-precious stones & 571 & 5 & 325 & 43.7 \\
\hline 16 & Electronic instruments, tape records, TV & 804 & 0 & 180 & 41.5 \\
\hline 17 & Transportation vehicles & 132 & 0 & 190 & Na \\
\hline 18 & Optics, cameras, medical and surgery & 238 & 5 & 145 & 35.6 \\
& instruments & & & & \\
\hline 19 & Guns and related items & 17 & 80 & 80 & 80 \\
\hline 20 & Sport goods and toys & 130 & 15 & 215 & 130.6 \\
\hline 21 & Paintings and antiques & 7 & 5 & 5 & 5 \\
\hline Sour & Razi Ali, rationaling tarf rates in Iran, & & 5 & 5 \\
\hline
\end{tabular}

Source: Razini Ali, rationalizing tariff rates in Iran, trade research center, ministry of commerce, 1999.

\begin{tabular}{llll}
\hline \multicolumn{5}{c}{ Table (4)- Tariff commitments of selected countries for industrial products in 1999 } \\
\hline Member & Percent of imports with bound tariffs & Current mean industrial tariff & Applied bound tariff \\
\hline Philippines & 67.4 & 9.1 & 21.3 \\
\hline Indonesia & 92.3 & 14.9 & 36.9 \\
\hline Malaysia & 79.3 & 9.4 & 8.9 \\
\hline Singapore & 96.5 & 2.7 & 6.9 \\
\hline Thailand & 67.4 & 43.7 & 27.3 \\
\hline Brazil & 100 & 18.3 & 27.7 \\
\hline Chile & 100 & 10.9 & 24.9 \\
\hline India & 69.3 & 29.5 & 34.2 \\
\hline Sri Lanka & 9.2 & 19.8 & 17.9 \\
\hline Turkey & 49.3 & 5.7 & 16.3 \\
\hline Zimbabwe & 13.6 & 20.5 & 23.6 \\
\hline Australia & 96.9 & 4.4 & 12.1 \\
\hline Canada & 99.8 & 3.2 & 4.3 \\
\hline European Union & 100 & 3.5 & 3.2 \\
\hline Korea & 89.9 & 7.8 & 6.9 \\
\hline Mexico & 100 & 12 & 33.3 \\
\hline United States & 100 & 2.7 & 3.5 \\
\hline SourcewWW. & &
\end{tabular}

Source:www.cementdistribution.com/industryinfo/trade.html

\section{Non-tariff barriers in Iran}

The Market Regulating Committee ${ }^{5}$ is in charge of cement pricing and has approved the following regulations in 2002 regarding the cement industry in Iran. According to these regulations, the clinker price for the year 2003 is obtained by adding up the base price in 2002 to 15 percent growth rate. The amount of sale by each company should be determined by a committee, which consists of the vice minister of commerce, vice minister of industries and vice minister of housing. According to the regulations approved by the cited committee, enterprises are obliged to use the difference between

\footnotetext{
5- A committee established for confronting with shortage of the essential goods and commodities which is under the control of the expediency council.
} 
controlled price and the equilibrium price for increasing the capacity of the cement industry. Meanwhile, the main shareholders of the cement industry including; Social Security Organization, Mostazafan and Janbazan Foundation, and the National Bank of Iran are responsible for importing cement or clinker according to the needs announced through the above-mentioned committee.

The controlled price will be set on a quarterly basis. In addition, the profit margins for the wholesale and retail sellers will be determined by this committee and will be approved by the Consumers and Producers Protection Organization (CPPO). The ministry of industries will be in charge of determining the cement prices in different enterprises, depending on the region and the quality of production. All producers and distributors are subject to administrative controlled prices. Moreover, the cement producers are responsible for allocating a portion of their profits for financing the difference in the controlled price and the import price of cement and clinker. Ministry of industries is responsible for the imports of clinker and cement. The Management and Planning Organization (MPO) and the Central Bank of Iran (CBI) are committed to providing financial facilities to respond to the needs of establishment and especially for increasing the existent capacities. However, white cement is excluded from the above-mentioned regulations.

As it is seen, the cement industry in Iran is heavily regulated and protected through different committees and organizations, which are involved in determining administrative controlled prices and distribution mechanism. Indeed, the industry has failed to respond to domestic demand due to the existence of tariff and non-tariff barriers. Accession to the World Trade Organization (WTO) requires removing the controlled prices, quantitative restrictions, and bans on imports and exports, which are all requirements for improving the competitiveness of the industry. Indeed, joining the WTO requires carrying out essential reforms to reduce the tariff rates substantially. To assess the effects of tariff reduction on the cement industry, the next section develops a structural system of equations, including supply, demand, exports, imports, and prices.

\section{Future Trade Prospects}

Trade prospects are good in the short-run and medium term. During 2000-2003 high oil prices have driven rapid import growth in the Persian Gulf economies, though beyond 2003, this factor may not sustain continued growth. In the medium term, WTO is becoming an increasingly important force for liberalization in the region, reducing tariff and removing non-tariff barriers, improving intellectual property right protection, deregulating and liberalizing agency arrangements and opening rapidly growing sectors such as telecommunications and e-technologies. Its influence is likely to increase if Saudi Arabia's accession is successful. Common GCC external tariffs may raise average tariffs in some of the region's most open economies, like the UAE and Kuwait; however, increased integration also can promote intraregional trade and hence manufacturer's ability to move beyond the Gulf region from base manufacturing, the oil.

In the medium term, Iran may become a substantially more important trading nation in the Persian Gulf region since she has rapid population growth and is willing to carry out economic reforms in accordance with WTO agreements.

\section{Methodology}

To determine the quantitative effects of Iran's joining WTO on her cement industry we try to build up a dynamic disequilibrium adjustment model (DDAM) to investigate the effects of tariff reductions on production, consumption, and trade, with emphasis on simultaneous domestic price effect in changing domestic production and consumption. The sample under investigation covers the period 1963-2002. The data on the cement industry has been obtained from the cement companies and macroeconomic data including GDP , cement wholesale price index, and Iran's effective exchange rate has been obtained from 
the data bank of the Central Bank of Iran. The world production and prices have been obtained from International Trade Statistics.

\section{List of Variables}

IRYCD=Iran's cement output (domestic supply)

IRIMP=Iran's cement imports in tons

IREXP=Iran's cement exports

WPRICE $=$ World price of cement

IRPRICE=Iran's approved cement price (Rials per ton)

IRWPRICE=Iran's cement wholesale price index

IRGDP=Iran's GDP at constant factor prices

IRGDPNF=Non oil GDP at factor costs

IREENOIL=Iran's effective exchange rate (Units of Rials per U.S. dollars)

EXCESS=Change in cement inventory in Iran

NCAPACITY=nominal capacity of cement production in Iran

$\mathrm{CONSD}=\mathrm{Cement}$ consumption of domestic production

Variables starting with "D" and following with two or four digit numbers are dummy variables whose values are one for the specific period denoted by digits and zero otherwise. The proposed DDAM consists of the following equations:

IRIMP=C(10)+C(11)*IRGDP+C(12)*IREENOIL*WPRICE/IRWPRICE+C(13)*IRIMP(-1)+

$\mathrm{C}(14) * \mathrm{D} 5972 * \operatorname{IRIMP}(-1)+\mathrm{C}(15) * \mathrm{D} 77+\mathrm{C}(16) * \mathrm{D} 79+\mathrm{C}(76) * \mathrm{D} 7905$

IREXP $=(1-\mathrm{D} 7286) *(\mathrm{C}(21) *$ NCAPACITY+C(22)*IREENOIL*WPRICE/IRWPRICE+ C(23)*IREXP(-

1))+C(24)*D0205+C(25)*D71

LOG(IRYCD) $=\mathrm{C}(30)+\mathrm{C}(31) * \mathrm{LOG}($ IRWPRICE) $+\mathrm{C}(32) * \mathrm{LOG}(\mathrm{NCAPACITY})+$

$\mathrm{C}(33) * \operatorname{LOG}(\operatorname{IRYCD}(-1))$

LOG(CONSD)=C(40)+C(41)*LOG(IRWPRICE)+C(42)*LOG(IRGDPNF)+C(43)*@ TREND+

$\mathrm{C}(44) * \mathrm{D} 5978$

LOG $($ IRWPRICE $)=(\mathrm{C}(51) * \mathrm{EXCESS}+\mathrm{C}(52) * \mathrm{LOG}(\operatorname{IRWPRICE}(-1))) *(1+\mathrm{C}(53) * \mathrm{D} 9405)$

EXCESS=IRYCD+IRIMP-CONSD-IREXP

TBALANCE $=$ IREXP-IRIMP

The interaction mechanism of the model is very simple. Import, export and domestic production and consumption of cement are determined by the first fourth equations, and the sixth identity calculates changes in the inventory of cement. Price of cement is determined by the fifth equation, which is a difference equation and can oscillate in varieties of ways based on its lags structure, parameters' signs and magnitudes. Cement price simultaneously is determined by the existence of this variable in the first four equations. 


\section{Estimated Results}

All equations have been estimated by OLS method. The estimated results suggest, as presented in Table (5) that all statistics are econometrically meaningful and statistically significant in all equations.

The estimated results suggest that cement import covaries positively and significantly with GDP and negatively with the real effective exchange rate. Export equation reveals the fact that cement export is significantly and positively related to nominal capacity and real effective exchange rate.

Cement production covaries positively and significantly with the cement wholesale price index through the size of influence is negligible. However, the nominal capacity has a positive and significant influence on domestic production. Domestic consumption is negatively and significantly related to the cement wholesale price index, as expected and positively and significantly in relation to GDP.

Table (5). Estimated results for the DDAM for the cement industry of Iran

\begin{tabular}{|c|c|c|c|c|c|}
\hline $\begin{array}{l}\text { Independent } \\
\text { variable }\end{array}$ & IRIMP & IREXP & IRYCD & CONSD & $\begin{array}{l}\text { IRWPRIC } \\
\text { E }\end{array}$ \\
\hline IRGDP & $\begin{array}{c}1.61 \\
(4.12)\end{array}$ & & & & \\
\hline IRGDPNF & & & & $\begin{array}{c}0.91 \\
(17.08)\end{array}$ & \\
\hline IRENONOIL & $\begin{array}{l}-167 \\
(-3.4)\end{array}$ & $\begin{array}{c}27.6 \\
(2.44)\end{array}$ & & & \\
\hline IRIMP (-1) & $\begin{array}{c}0.55 \\
(11.3)\end{array}$ & & & & \\
\hline NCAPACITY & & $\begin{array}{c}0.69 \\
(2.27) \\
\end{array}$ & $\begin{array}{c}0.27 \\
(3.87) \\
\end{array}$ & & \\
\hline IREXP(-1) & & $\begin{array}{c}0.32 \\
(1.97)\end{array}$ & & & \\
\hline IRWPRICE & & & $\begin{array}{c}0.02 \\
(2.41)\end{array}$ & $\begin{array}{c}-0.20 \\
(-7.51)\end{array}$ & $\begin{array}{c}1.08 \\
(62.13)\end{array}$ \\
\hline IRYCD(-1) & & & $\begin{array}{c}0.59 \\
(7.25) \\
\end{array}$ & & \\
\hline EXCESS & & & & & $\begin{array}{c}8.46 \mathrm{E}-08 \\
(2.55) \\
\end{array}$ \\
\hline R-Squared & 0.97 & 0.88 & 0.99 & 0.99 & 0.99 \\
\hline Adjusted R-squared & 0.97 & 0.87 & 0.99 & 0.99 & 0.99 \\
\hline Durbin-Watson & 1.29 & 1.76 & 2.10 & 1.34 & 1.20 \\
\hline
\end{tabular}

To analyze the effects of Iran's WTO accession on the Iranian cement industry we solve the model for the period of 1993-2002 by stochastic simulation with 1000 replication to find out the baseline scenario which is used as a control solution to compare with an alternative scenario which has been modified to measure Iran's WTO joining effect. The result of the baseline solution model is presented in Annex 1.

Since the data on tariff rate for the time period under investigation is not available, to measure the effects of tariff reduction within the model, we decrease book price of cement both for imports and exports to be in conformity with WTO agreements. To do so, we multiply the real effective exchange rate variable in both import demand and export supply equations of the model by $(1-\alpha)$, where $\alpha$ is the percentage of tariff reduction that may be proposed by WTO. The results are presented in Annex 2.

To measure the amount of tariff reduction, we use pre and post WTO joining tariff profiles for imports of industrial products by the country group as a proxy for the tariff reduction rate. According to unbalanced 
tariff reductions for developed and less developed countries, and regarding previous studies ${ }^{6}$ we adopt to apply 69\% tariff reduction on Iran's import of cement from DCs and 14\% tariff reduction for Iran's exports to DCs. Though these numbers are guess estimates but can show the effects of joining WTO on Iran's cement economics. Using stochastic simulation of model 2 with the same characteristics of model 1, regarding the sample period and 1000 replication, we produced the alternative solution which can be compared with the control solution (Annex 3).

The following graphs and tables compare the mean and standard deviations of these two solutions. The results of the simulations are presented in Annex 4.

In sum, the estimated results and simulations indicate that Iran's joining WTO:

- Does not affect her domestic cement consumption.

- Has negligible decreasing effects on cement exports

- Will dramatically increase Iran's cement imports

- Price adjustment is as dynamic as changes in total cement demand and supply and will adjust itself more rapidly after joining WTO

- Changes in domestic supply will be negligible after joining WTO

- All in all, joining WTO may cause the cement trade deficit
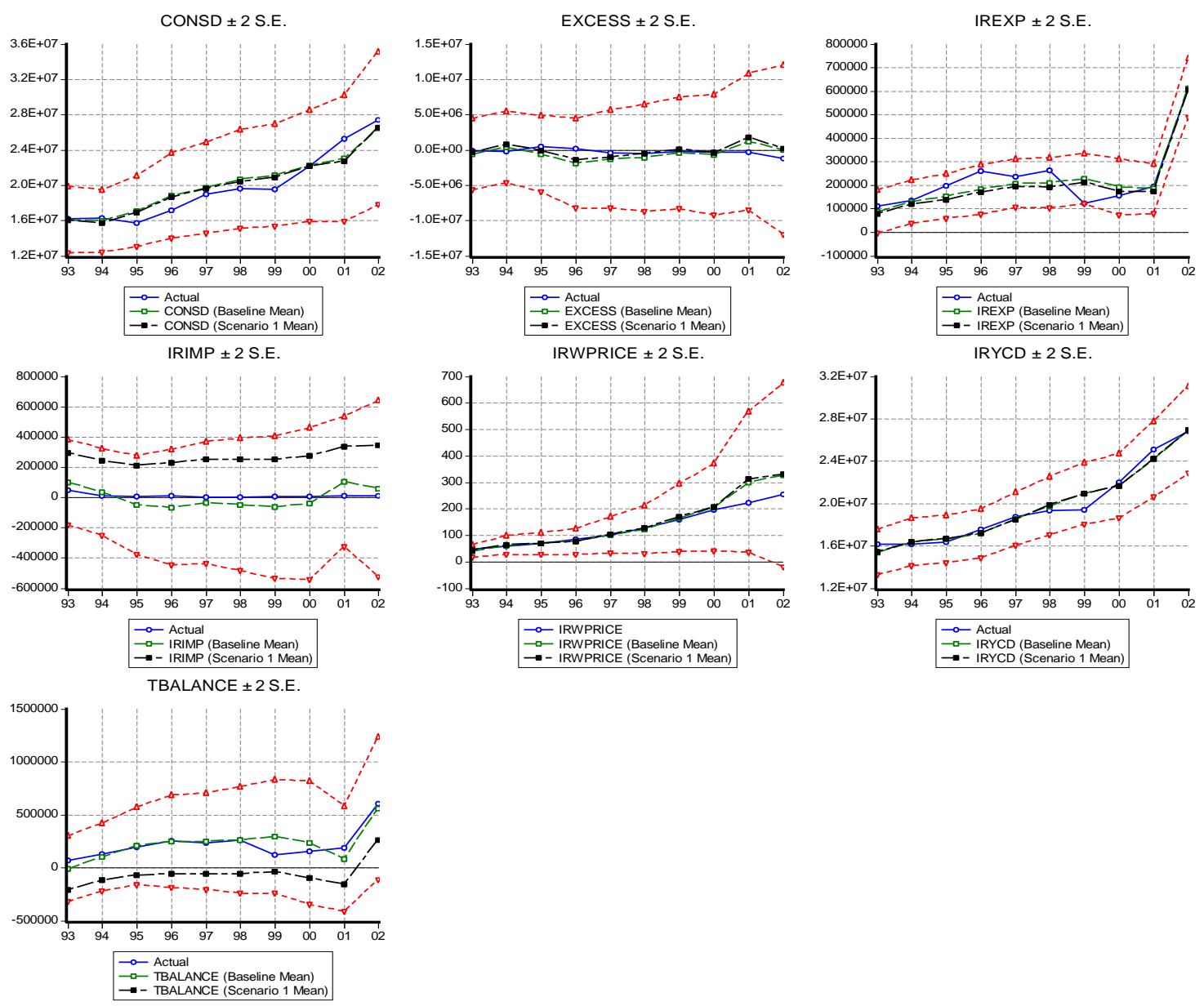

\footnotetext{
${ }^{6}$ Bidabad B., "Designing econometric model to measure the changes in imports and exports of the industry sector", Chapter 5 , 1996.

"Quantitative effects of joining WTO on Iran industrial sector", 2004.
} 


\section{Conclusion}

Iran has a unique geographical situation in the Persian Gulf region for boosting trade in different commodities, especially minerals. Reducing oil dependency as one of the main objectives of the Five Years Development Plans has induced the Iranian officials to undertake some essential reforms in trade and government policies. Though Iran still suffers from high levels of tariff and non-tariff barriers on her trade relations and internal obstacles on domestic industries, in the medium term, Iran may become a substantially more important trading nation in the Persian Gulf region since she has rapid population growth and is willing to carry out economic reforms.

The administrative price controls besides import compression policy have contributed to the low level of cement production. Iran's import profile is heavily skewed towards those tradable that are not strongly under the effects of WTO, indicating protectionism in the industry sector. Trade liberalization that has been carried among the Persian Gulf region's economies provides a supportive argument for Iran's accession to WTO. Since countries' experiences provide a contradictory profile after joining WTO, this paper tried to investigate the quantitative effects of the entry accession on the cement industry of Iran.

To do so, we developed a dynamic disequilibrium adjustment model (DDAM) with data covering the period 1963-2002. Assuming 69 percent tariff reduction on Iran's imports of cement from DCs and 14 percent tariff reduction for Iran's exports to DCs after accession and applying stochastic dynamic simulation results for the period 1993-2002 with one thousand replications suggest that Iran's accession to WTO has negligible effects on her domestic consumption, production, and exports, while it substantially raises its cement imports.

All in all, the results suggest that Iran's WTO accession does not have tremendous effects on its production, exports, and consumption. Though the entry may accelerate cement imports. Since the cement is used as an essential input for the industry and real-estate sectors, which has highly contributed to the GDP growth in recent years, it is expected that it may contribute to a higher level of economic growth in years to come.

To pave the way for joining WTO, Iran has to take important measures to liberalize controlled prices, to remove quantitative restrictions, and to deregulate the industry in conformity with WTO arrangements.

\section{References}

Balassa B. (1971). The structure of protection in developing countries. John Hopkins Press, Baltimore.

Baldwin, Richard E. (2000), Regulatory protectionism developing nations, and a two-tier world trade system.

Bidabad, Bijan. (1994). Quantitative effects of joining WTO on Iran industrial sector.

Bidabad, Bijan.(1994). Designing an econometric model to measure the changes in imports and exports of the industry sector, Chapter 5.

Bidabad, Bijan; Mahshid Sherafati, Roohollah Mohammadi.(2014).Measuring Efficiency of Production and Cost in Abyek Cement Factory Using Operational and Efficient Production Functions. International Conference on Business Strategy and Social Sciences (ICBSSS), Asian Economic and Social Society (AESS), Faculty of Technology Management and Business, Universiti Tun Hussein Onn Malaysia, and Pak Publishing Group. 16-17 August 2014, Kuala Lumpur, Malaysia. http://www.bidabad.com/doc/abyekfunction-en.pdf

Bidabad, Bijan; Mahshid Sherafati, Roohollah Mohammadi.(2014).A Financial Model for Economic Analysis of Cement Factory. International Conference on Business Strategy and Social Sciences (ICBSSS), Asian Economic and Social Society (AESS), Faculty of Technology Management and Business, Universiti Tun Hussein Onn Malaysia, and Pak Publishing Group. 16-17 August 2014, Kuala Lumpur, Malaysia. http://www.bidabad.com/doc/abyekanalysis-short-en.pdf 
Bora, B., A. Kuwahara, S., Laird. (2002). Quantification of non-tariff measures, Policy issues in international trade and commodities, study series no. 18. United Nations, Trade Analysis Branch, Division on International Trade in Goods and Services, and Commodities, United Nations Conference on Trade and Development (UNCTAD), Geneva, Switzerland. http://r0.unctad.org/p166/module2002Bangk/Module4/boralairdkuwa.pdf

Borland, B., 2000, Gulf 2000: The WTO and GCC, paper presented at the Gulf 2000: Energy Infrastructure and Finance Conference, Abu Dhabi, 28 and 29 March

Bosworth, Malcom .(1999). Non-Tariff measures as trade barriers: yesterday problem or what? Paper prepared for the OECD workshop with non-member economies on barriers to trade in goods and services in the post-Uruguay round context. Paris, 27-28 September.

Bouet, A., L. Fontagne, M. Mimouni, X. Pichot (2001), Market access maps: A bilateral and disaggregated measure of market access.

Corden W.M. .(1971). The theory of protection. Clarendon Press, Oxford.

Dadras, R. 1999, 'Measuring the technical efficiency of the cement industry in Iran, a dissertation guided by Dr. B. H. Zonooz, Allameh University, Tehran.

Deardorff, A., R. Stern. (1998). The measurement of non-tariff barriers, OECD, Economic Department Working Papers No. 179, OECD, Washington.

Fieleke N.S. (1995) The Uruguay round of trade negotiations. Industrial and geographic effects in the United States. New England economic review. Federal Reserve Bank of Boston. July/August.

Fieleke N.S. (1995) The Uruguay round of trade negotiations. Industrial and geographic effects in the United States. New England economic review, Federal Reserve Bank of Boston, May/June.

General Agreement on Tariffs and Trade. "The results of the Uruguay round of multilateral trade negotiations", Geneva, November 1994.

Heller H.R. (1995) International trade, theory and empirical evidence, prentice hall of India, New Delhi.

http://heiwww.unige.ch/ baldwin/papers/NTBs_brookings_trade_forum00_baldwin.pdf

Intriligator M.D. (1978). Econometric models, techniques, and applications. North-Holland publishing company.

Mohammed Reza Raf'ati, 1995, ' Iran's standing in Global Trade and Upshots of Membership the GATT, Payame Darya (Economic-Scientific Monthly), Vol. 4, No.33, pp. 14-25.

Razini Ali, rationalizing tariff rates in Iran, trade research center, ministry of commerce, 1999.

Sameti, M., 1995. 'Reducing Government Interventions', Ministry of Economic Affairs and Finance, Tehran, Iran.

http://www.cepii.fr/anglaisgraph/communications/pdf/2001/washington/macmaps.pdf

http://www.nuca.ie.ufrj.br/infosucro/biblioteca/negociacoes/Baldwin_regulatory.pdf

Annex 1

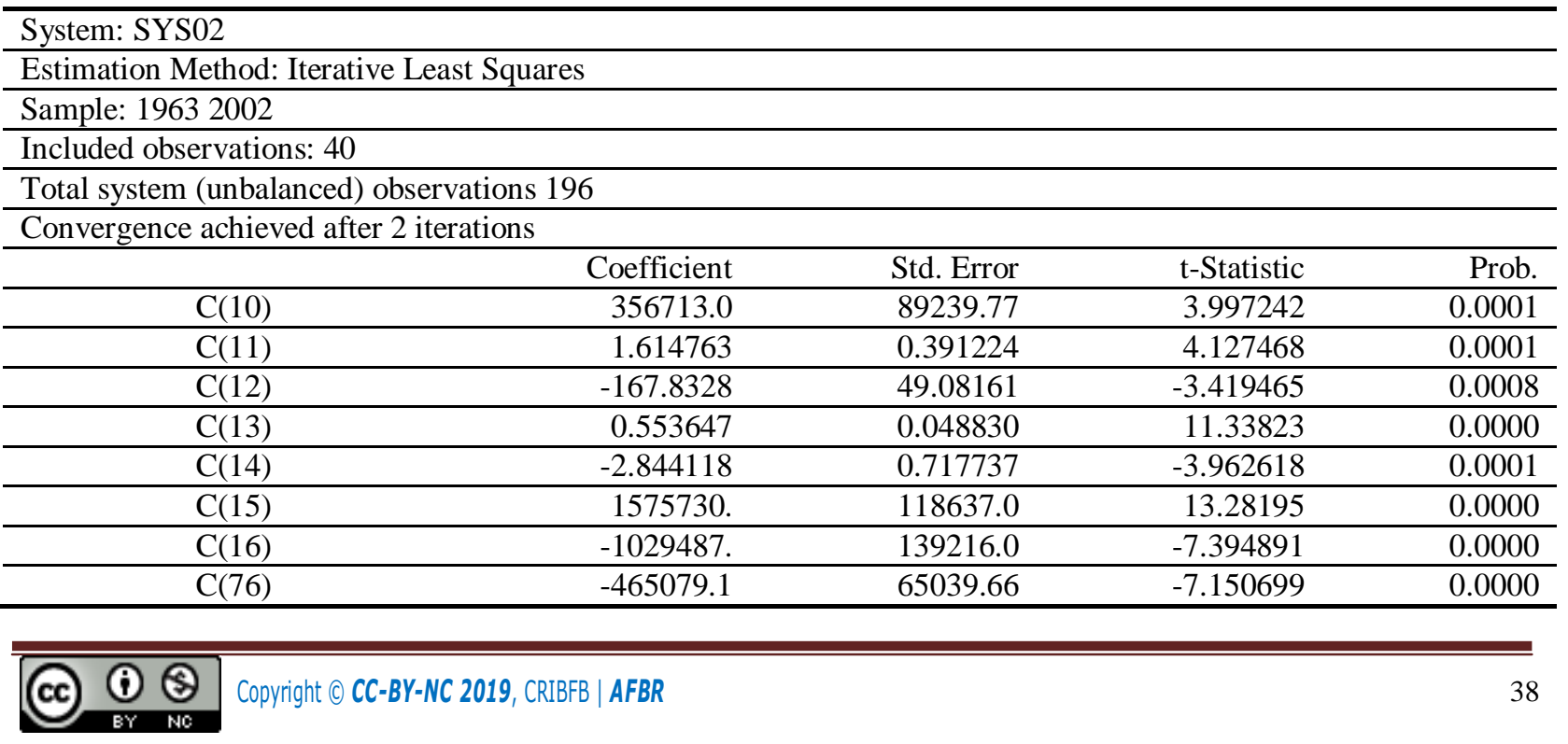




\begin{tabular}{|c|c|c|c|c|}
\hline $\mathrm{C}(21)$ & 0.693379 & 0.305329 & 2.270925 & 0.0244 \\
\hline $\mathrm{C}(22)$ & 27.63896 & 11.29419 & 2.447184 & 0.0154 \\
\hline $\mathrm{C}(23)$ & 0.324899 & 0.164908 & 1.970181 & 0.0504 \\
\hline $\mathrm{C}(24)$ & 394125.0 & 47465.98 & 8.303316 & 0.0000 \\
\hline$C(25)$ & 174850.0 & 45179.54 & 3.870114 & 0.0002 \\
\hline $\mathrm{C}(30)$ & 3.553863 & 0.626057 & 5.676581 & 0.0000 \\
\hline $\mathrm{C}(31)$ & 0.029530 & 0.012247 & 2.411316 & 0.0170 \\
\hline $\mathrm{C}(32)$ & 0.271043 & 0.069899 & 3.877621 & 0.0002 \\
\hline $\mathrm{C}(33)$ & 0.598896 & 0.082511 & 7.258341 & 0.0000 \\
\hline $\mathrm{C}(40)$ & 4.136804 & 0.553261 & 7.477131 & 0.0000 \\
\hline $\mathrm{C}(41)$ & -0.208590 & 0.027749 & -7.517172 & 0.0000 \\
\hline $\mathrm{C}(42)$ & 0.910048 & 0.053252 & 17.08955 & 0.0000 \\
\hline $\mathrm{C}(43)$ & 0.059990 & 0.006514 & 9.208956 & 0.0000 \\
\hline $\mathrm{C}(44)$ & -0.267502 & 0.044555 & -6.003929 & 0.0000 \\
\hline $\mathrm{C}(51)$ & $8.46 \mathrm{E}-08$ & $3.31 \mathrm{E}-08$ & 2.557616 & 0.0114 \\
\hline$C(52)$ & 1.089052 & 0.017527 & 62.13742 & 0.0000 \\
\hline $\mathrm{C}(53)$ & -0.040562 & 0.018605 & -2.180109 & 0.0306 \\
\hline Determinant residual covariance & & $3.07 \mathrm{E}+12$ & & \\
\hline \multicolumn{5}{|c|}{ Equation: IRIMP=C(10)+C(11)*IRGDP+C(12)*IREENOIL*WPRICE /IRWPRICE+ } \\
\hline \multicolumn{5}{|c|}{$\mathrm{C}(13) * \operatorname{IRIMP}(-1)+\mathrm{C}(14) * \mathrm{D} 5972 * \operatorname{IRIMP}(-1)+\mathrm{C}(15) * \mathrm{D} 77+\mathrm{C}(16) * \mathrm{D} 79+\mathrm{C}(76) * \mathrm{D} 7905$} \\
\hline \multicolumn{5}{|c|}{ Observations: 39} \\
\hline R-squared & 0.977260 & Mean dependent var & & 263560.7 \\
\hline Adjusted R-squared & 0.972125 & S.D. dependent var & & 620654.5 \\
\hline S.E. of regression & 103623.4 & Sum squared resid & & $3.33 \mathrm{E}+11$ \\
\hline Durbin-Watson stat & 1.296946 & & & \\
\hline \multicolumn{5}{|c|}{ Equation: IREXP $=(1-\mathrm{D} 7286) *(\mathrm{C}(21) * \mathrm{NCAPACITY}+\mathrm{C}(22) * \mathrm{IREENOIL}$} \\
\hline \multicolumn{5}{|c|}{$*$ WPRICE/IRWPRICE+C(23)*IREXP(-1))+C(24)*D0205+C(25)*D71 } \\
\hline \multicolumn{5}{|c|}{ Observations: 39} \\
\hline R-squared & 0.885778 & Mean dependent var & & 93074.18 \\
\hline Adjusted R-squared & 0.872340 & S.D. dependent var & & 120420.2 \\
\hline S.E. of regression & 43025.50 & Sum squared resid & & $6.29 \mathrm{E}+10$ \\
\hline Durbin-Watson stat & 1.767650 & & & \\
\hline \multicolumn{5}{|c|}{ Equation: LOG(IRYCD)=C(30)+C(31)*LOG(IRWPRICE)+C(32) } \\
\hline \multicolumn{5}{|c|}{$*$ LOG(NCAPACITY)+C(33)*LOG(IRYCD(-1)) } \\
\hline \multicolumn{5}{|l|}{ Observations: 39} \\
\hline R-squared & 0.995544 & Mean dependent var & & 15.84935 \\
\hline Adjusted R-squared & 0.995162 & S.D. dependent var & & 0.927457 \\
\hline S.E. of regression & 0.064510 & Sum squared resid & & 0.145656 \\
\hline Durbin-Watson stat & 2.109574 & & & \\
\hline \multicolumn{5}{|c|}{ Equation: $\mathrm{LOG}(\mathrm{CONSD})=\mathrm{C}(40)+\mathrm{C}(41) * \mathrm{LOG}(\mathrm{IRWPRICE})+\mathrm{C}(42)$} \\
\hline \multicolumn{5}{|c|}{ *LOG(IRGDPNF)+C(43)*@TREND+C(44)*D5978 } \\
\hline \multicolumn{5}{|l|}{ Observations: 40} \\
\hline R-squared & 0.995519 & Mean dependent var & & 15.79203 \\
\hline Adjusted R-squared & 0.995006 & S.D. dependent var & & 0.989941 \\
\hline S.E. of regression & 0.069955 & Sum squared resid & & 0.171278 \\
\hline Durbin-Watson stat & 1.347284 & & & \\
\hline \multicolumn{5}{|c|}{ Equation: $\mathrm{LOG}(\mathrm{IRWPRICE})=(\mathrm{C}(51) * \mathrm{EXCESS}+\mathrm{C}(52) * \mathrm{LOG}(\mathrm{IRWPRICE}(-1))) *(1+\mathrm{C}(53) * \mathrm{D} 9405)$} \\
\hline \multicolumn{5}{|l|}{ Observations: 39} \\
\hline R-squared & 0.994469 & Mean dependent var & & 2.031391 \\
\hline Adjusted R-squared & 0.994161 & S.D. dependent var & & 1.888493 \\
\hline S.E. of regression & 0.144301 & Sum squared resid & & 0.749616 \\
\hline Durbin-Watson stat & 1.205921 & & & \\
\hline
\end{tabular}



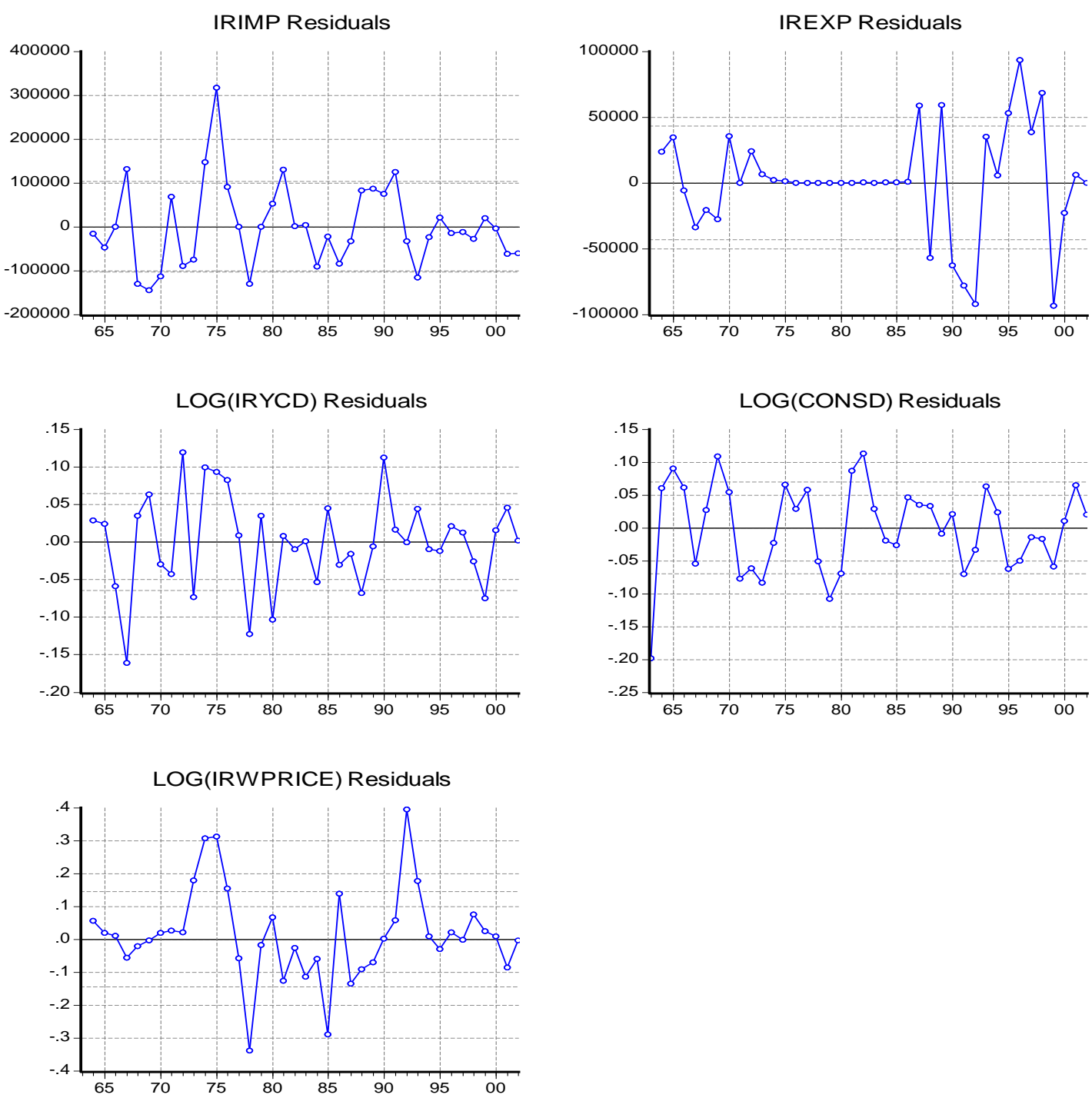

Annex 2. Model for Baseline Solution

IRIMP=356712.976885967+1.61476270618398*IRGDP-167.832811413045*IREENOIL*

WPRICE/IRWPRICE+0.553647193085624*IRIMP(-1)-2.84411769308308*D5972*IRIMP(-

1)+1575730.35363319*D77-1029487.01407616*D79-465079.055437859*D7905

@INNOV IRIMP 103623.3858

IREXP $=(1-\mathrm{D} 7286) *(0.693379435212086 * \mathrm{NCAPACITY}+27.6389569885331 *$ *REENOIL *

WPRICE/IRWPRICE+0.324898912988592*IREXP(-1))+394125.044423648* D0205+

$174849.960849296 * \mathrm{D} 71$

@INNOV IREXP 43025.49704 
LOG $($ IRYCD $)=3.55386253259695+0.0295302269682137 *$ LOG $($ IRWPRICE $)+0.271043101241564 *$ LO G(NCAPACITY)+0.598896470243663*LOG(IRYCD(-1))

@INNOV IRYCD 0.06451036764

$\mathrm{LOG}(\mathrm{CONSD})=4.13680392769509$ -

0.20859037839689*LOG(IRWPRICE)+0.910047792543505*LOG(IRGDPNF)+0.0599895559828637*

@TREND-0.267502133314843*D5978

@INNOV CONSD 0.06995458186

LOG $($ IRWPRICE $)=(8.45645793256322 \mathrm{e}-08 *$ EXCESS $+1.08905173285413 *$ LOG $($ IRWPRICE $(-1))) *(1-$

$0.0405615985167576 * \mathrm{D} 9405)$

@INNOV IRWPRICE 0.1443005985

@IDENTITY EXCESS=IRYCD+IRIMP-CONSD-IREXP

@IDENTITY TBALANCE=IREXP- IRIMP

Annex 3. Model for Alternative Scenario Solution

IRIMP=356712.976885967+1.61476270618398*IRGDP-167.832811413045*(1-0.69)* IREENOIL*

WPRICE/IRWPRICE+0.553647193085624*IRIMP(-1)-2.84411769308308* D5972*IRIMP(-

1)+1575730.35363319*D77-1029487.01407616*D79-465079.055437859*D7905

@INNOV IRIMP103623.3858

IREXP $=(1-D 7286) *(0.693379435212086 * N C A P A C I T Y+27.6389569885331 *(1-0.14) *$

IREENOIL*WPRICE/IRWPRICE+0.324898912988592*IREXP(-1))+

394125.044423648*D0205+174849.960849296*D71

@INNOV IREXP43025.49704

LOG $($ IRYCD $)=3.55386253259695+0.0295302269682137 *$ LOG $($ IRWPRICE $)+0.271043101241564 *$ LO

G(NCAPACITY)+0.598896470243663*LOG(IRYCD(-1))

@INNOV IRYCD0.06451036764

LOG(CONSD $)=4.13680392769509-0.20859037839689 *$ LOG $($ IRWPRICE $)+$

0.910047792543505*LOG(IRGDPNF)+0.0599895559828637*@TREND-0.267502133314843*D5978

@INNOV CONSD0.06995458186

LOG $($ IRWPRICE $)=(8.45645793256322 \mathrm{e}-08 *$ EXCESS $+1.08905173285413 *$

LOG(IRWPRICE(-1)))*(1-0.0405615985167576*D9405)

@INNOV IRWPRICE0.1443005985

@IDENTITY EXCESS=IRYCD+IRIMP-CONSD-IREXP

@IDENTITY TBALANCE=IREXP-IRIMP 


\section{Annex 4. Simulation results}

\begin{tabular}{|c|c|c|c|c|c|c|c|c|c|c|}
\hline & 1993 & 1994 & 1995 & 1996 & 1997 & 1998 & 1999 & 2000 & 2001 & 2002 \\
\hline \multicolumn{11}{|l|}{ CONSD } \\
\hline \multirow[t]{2}{*}{ Actual } & 162065 & 162664 & 156783 & 171079 & 189310 & 195837 & 195009 & 220950 & 252683 & 2740193 \\
\hline & 54 & 73 & 50 & 58 & 72 & 44 & 37 & 48 & 41 & 7 \\
\hline \multirow{2}{*}{ Baseline } & 160378 & 159024 & 170185 & 187991 & 196545 & 206607 & 211199 & 221799 & 229871 & 2644272 \\
\hline & 84 & 30 & 63 & 38 & 92 & 99 & 47 & 57 & 99 & 1 \\
\hline \multirow[t]{2}{*}{ S.E. } & 189530 & 177855 & 199889 & 242584 & 258778 & 279584 & 289242 & 315305 & 356637 & 4324011 \\
\hline & 8 & 4 & 3 & 2 & 8 & 5 & 8 & 0 & 8 & \\
\hline \multirow[t]{2}{*}{ Scenario 1} & 159762 & 156799 & 169063 & 186323 & 195647 & 204079 & 208858 & 221704 & 227162 & 2648527 \\
\hline & 23 & 65 & 97 & 74 & 76 & 61 & 06 & 49 & 77 & 8 \\
\hline \multirow[t]{2}{*}{ S.E. } & 184489 & 170640 & 189683 & 221846 & 255274 & 265193 & 281484 & 311062 & 336131 & 4625671 \\
\hline & 9 & 1 & 8 & 3 & 5 & 9 & 2 & 9 & 3 & \\
\hline \multicolumn{11}{|l|}{ EXCESS } \\
\hline \multirow[t]{2}{*}{ Actual } & - & - & 484747 & 184983 & - & - & - & - & - & - \\
\hline & 122047 & 254573 & & & 467738 & 520582 & 235484 & 298363 & 373231 & 1201499 \\
\hline \multirow{3}{*}{ Baseline } & - & 337059 & - & - & - & - & - & - & 110986 & -57875 \\
\hline & 653809 & & 631364 & 193253 & 137618 & 117860 & 490759 & 763234 & 0 & \\
\hline & & & & 2 & 2 & 8 & & & & \\
\hline \multirow[t]{2}{*}{ S.E. } & 254328 & 251518 & 270573 & 317882 & 347307 & 380232 & 393140 & 426033 & 483606 & 6000669 \\
\hline & 1 & 1 & 6 & 9 & 7 & 2 & 6 & 5 & 4 & \\
\hline \multirow[t]{2}{*}{ Scenario 1} & - & 788030 & - & - & - & - & 47128 & - & 169112 & 176323 \\
\hline & 353901 & & 196046 & $\begin{array}{r}140545 \\
1\end{array}$ & $\begin{array}{r}101910 \\
6\end{array}$ & 530351 & & 413340 & 8 & \\
\hline \multirow[t]{2}{*}{ S.E. } & 247505 & 241068 & 255582 & 289040 & 332797 & 350623 & 373277 & 401788 & 448301 & 6098156 \\
\hline & 9 & 5 & 6 & 6 & 4 & 4 & 5 & 8 & 7 & \\
\hline \multicolumn{11}{|l|}{ IREXP } \\
\hline Actual & 111239 & 134488 & 197054 & 260388 & 235238 & 261208 & 122375 & 155087 & 194850 & 610693 \\
\hline Baseline & 86759 & 128144 & 152419 & 180749 & 206906 & 207866 & 225355 & 190251 & 183278 & 612082 \\
\hline S.E. & 46090 & 46387 & 47534 & 53072 & 51064 & 53496 & 53706 & 60049 & 53014 & 63026 \\
\hline Scenario 1 & 78532 & 120113 & 138204 & 169730 & 194205 & 191684 & 210607 & 173976 & 173039 & 603892 \\
\hline S.E. & 45263 & 45866 & 46397 & 47404 & 47280 & 47773 & 49995 & 53907 & 48096 & 60812 \\
\hline \multicolumn{11}{|l|}{ IRIMP } \\
\hline Actual & 46985 & 7876 & 6205 & 7717 & 1369 & 917 & 4633 & 5906 & 8234 & 9944 \\
\hline Baseline & 98823 & 31597 & -52485 & -66917 & -36401 & -49132 & -66666 & -43403 & 101500 & 54936 \\
\hline S.E. & 141048 & 143723 & 164024 & 190253 & 201540 & 218589 & 234663 & 251001 & 215611 & 291782 \\
\hline Scenario 1 & 291764 & 239516 & 210658 & 227560 & 251176 & 251709 & 251855 & 275379 & 333432 & 344262 \\
\hline S.E. & 106942 & 108506 & 106966 & 114738 & 117116 & 118803 & 115158 & 128777 & 109627 & 141848 \\
\hline \multicolumn{11}{|l|}{ IRWPRICE } \\
\hline Actual & 48.0 & 56.4 & 68.2 & 85.3 & 100.0 & 126.9 & 158.4 & 195.8 & 220.9 & 254.2 \\
\hline Baseline & 40.1 & 61.0 & 67.3 & 75.2 & 99.4 & 120.3 & 164.0 & 204.2 & 299.6 & 326.4 \\
\hline S.E. & 11.9 & 18.1 & 20.1 & 24.9 & 34.1 & 45.5 & 64.3 & 82.5 & 133.1 & 173.7 \\
\hline Scenario 1 & 41.0 & 63.2 & 69.3 & 77.4 & 101.7 & 126.0 & 168.3 & 207.1 & 312.5 & 331.3 \\
\hline S.E. & 12.0 & 17.5 & 19.8 & 24.5 & 35.0 & 44.4 & 62.2 & 80.4 & 133.9 & 175.9 \\
\hline \multicolumn{11}{|l|}{ IRYCD } \\
\hline Actual & 161487 & 161385 & 163539 & 175456 & 186972 & 193234 & 193831 & 219458 & 250817 & 2680118 \\
\hline & 61 & 12 & 46 & 12 & 03 & 53 & 95 & 67 & 25 & 8 \\
\hline Baseline & 153720 & 163360 & 165921 & 171142 & 185217 & 197391 & 209212 & 216503 & 241788 & 2694199 \\
\hline & 11 & 36 & 02 & 71 & 17 & 88 & 09 & 77 & 38 & 2 \\
\hline S.E. & 106335 & 112759 & 111892 & 116522 & 125557 & 137305 & 146096 & 152440 & 178744 & 2046775 \\
\hline & 0 & 7 & 6 & 8 & 9 & 3 & 6 & 8 & 9 & \\
\hline Scenario 1 & 154090 & 163485 & 166378 & 171690 & 184886 & 198175 & 208916 & 216557 & 242470 & 2692123 \\
\hline & 91 & 91 & 95 & 92 & 99 & 85 & 87 & 05 & 13 & 2 \\
\hline S.E. & 109221 & 118091 & 112483 & 118349 & 128232 & 139980 & 149520 & 149853 & 170371 & 2072341 \\
\hline & 5 & 1 & 3 & 4 & 1 & 6 & 0 & 0 & 2 & \\
\hline TBALANCE & & & & & & & & & & \\
\hline Actual & 64254 & 126612 & 190849 & 252671 & 233869 & 260291 & 117742 & 149182 & 186615 & 600749 \\
\hline Baseline & -12064 & 96547 & 204903 & 247666 & 243306 & 256998 & 292021 & 233654 & 81778 & 557145 \\
\hline
\end{tabular}




\begin{tabular}{crrrrrrrrrr}
\hline S.E. & 156447 & 160653 & 183615 & 218804 & 228204 & 250681 & 267514 & 291900 & 248578 & 338083 \\
\hline Scenario 1 & - & - & -72455 & -57830 & -56971 & -60025 & -41247 & - & - & 259630 \\
& 213231 & 119403 & & & & & & 101403 & 160392 & \\
\hline S.E. & 118499 & 123734 & 121384 & 129132 & 135799 & 137472 & 135965 & 156101 & 127913 & 179772 \\
\hline
\end{tabular}

\section{Copyrights}

Copyright for this article is retained by the author(s), with first publication rights granted to the journal. This is an open-access article distributed under the terms and conditions of the Creative Commons Attribution license (http://creativecommons.org/licenses/by/4.0/). 